Wawasan:

Jurnal Kediklatan Balai Diklat Keagamaan Jakarta

PISSN: 2548-9232; EISSN: 2775-3573

Volume 2 Nomor 2 Tahun 2021: 134-143

\title{
PEMBELAJARAN AKTIF PADA PELATIHAN GURU MATEMATIKA MADRASAH IBTIDAIYAH
}

\author{
Asih Aryani \\ Balai Diklat Keagamaan Bandung, Indonesia \\ E-mail: asiharyani@yahoo.com
}

\begin{abstract}
This study aims to determine the impact MIKiR active learning method in training of Madrasah Ibtidaiyah mathematics teachers training. The research is Pre experimental design using one class as an experiment without a control class with a sample of 30 people. The data collection methods are observation and test. Data were analyed through descriptive statistics. The results showed that after using the MIKiR methode the average score of affective is 89.60 , the average score of knowledge is 90.17 and the average score of skillsis 89.88. Overall, an average of 89.94 was obtained. Researcher recommends conducting further research to measure the effectiveness of the method.
\end{abstract}

Keywords: training, teachers, active learning, MIKiR methode.

\begin{abstract}
Abstrak
Penelitian ini bertujuan untuk mengetahui dampak pembelajaran aktif MIKiR pada Pelatihan Guru Matematika Madrasah Ibtidaiyah. Jenis penelitian yang digunakan adalah Pre-Experimental Design dengan menggunakan satu kelas sebagai eksperimen tanpa kelas kontrol dengan sampel sebanyak 30 orang. Metode pengumpulan data yang digunakan adalah metode pengamatan dan tes. Tteknik analisis data yang digunakan adalah statistik deskriptif dengan menggunakan rata-rata dan prosentase. Hasil penelitian menunjukkan bahwa pembelajaran aktif MIKiR berhasil meningkatkan kompetensi peserta pelatihan aspek sikap dengan rata-rata 89,60, pengetahuan dengan rata-rata 90,17 dan keterampilan dengan rata-rata 89,88. Secara keseluruhan diperoleh rata-rata 89,94. Selanjutnta direkomendasikan untuk menguji metode ini secara experiment.
\end{abstract}

Kata kunci: pelatihan, guru, pembelajaran aktif MIKiR 


\section{PENDAHULUAN}

Kegiatan mengajar merupakan salah satu bentuk kegiatan memberikan layanan pada peserta didik yang didasari dan direncanakan serta dipersiapkan oleh seorang guru (Gani, Abd., 2021). Sebagai sentral dari kegiatan pembelajaran, maka guru harus selalu memperhatikan kompetensi yang akan dicapai pada setiap pembelajarannya, karena keberhasilan pencapaian kompetensi pada kegiatan proses belajar mengajar di satuan pendidikan tergantung kepada beberapa aspek yaitu kurikulum, sarana dan prasarana, guru, peserta didik dan metode/strategi (Kadariah, 2018) dan (Abdullah, 2017). Penggunaan strategi dalam kegiatan proses pembelajaran sangat diperlukan, karena untuk mempermudah pencapaian hasil pembelajaran yang optimal. Peran guru sebagai desainer diharapkan mampu merancang dan memenej apa yang distandarkan menjadi pembelajaran yang berhasil dan efektif. Guru Sebaiknya mampu menciptakan pembelajaran yang bermakna dan pada akhirnya dapat menumbuhkan motifasi pada pembelajar-pembelajar untuk mau dan mampu menerapkan ilmu yang disajikan oleh gurunya (Saefuddin, 2014).

Proses pembelajaran merupakan pemberian stimulus kepada peserta didik, kesiapan peserta didik dalam mengikuti proses pembelajaran akan menimbulkan respons, sehingga hubungan antara stimulus dan respons akan menjadi lebih baik kalau mampu menghasilkan hal-hal yang menyenangkan (Suprapto, 2018).

Prinsip pembelajaran adalah segala kondisi yang selalu ada pada setiap proses belajar, berbagai teori pembelajaran mengatakan bahwa setiap proses pembelajaran seharusnya memiliki suatu prinsip tertentu (Novianingsih, 2016), sehingga seorang guru dipastikan memiliki salah satu prinsip tersebut. Tiga aspek penting dalam pembelajaran yang saling terkait, yaitu materi pembelajaran, proses pembelajaran serta hasil dari proses pembelajaran tersebut (Hidayat, 2020). Guru harus memiliki cara atau strategi yang akan dipakainya dalam memberikan atau melaksanakan kegiatan pembelajaran.

Strategi pembelajaran adalah salah cara untuk membantu suksesnya proses pembelajaran, karena pada strategi pembelajaran terdapat desain atau rancangan yang bertujuan mencapai tujuan pendidikan secara menyeluruh (Yuanita, 2020). Seorang pendidik (guru) semestinya memiliki ide atau kreatifitas dalam mengetahui permasalahan peserta didiknya, terkadang harus menggunakan pendekatan individual untuk memotivasi belajar peserta didik, memberi sangsi bagi peserta didik yang melakukan kesalahan agar menjadi lebih teliti dan berhati-hati dalam melakukan tindakan dan memberikan bimbingan pada peserta didik yang 
masih belum faham dengan pelajaran yang telah diberikan (Yuanita, 2020).

Keaktifan seorang peserta didik dalam kegiatan pembelajaran akan mempengaruhi interaksi yang tinggi antara pendidik dengan peserta didik atau peserta didik dengan peserta didik lainnya pada kelas tersebut, sehingga akan terjadi komunikasi yang multi arah. Pada pelaksanaan pembelajaran dengan strategi pembelajaran aktif, peserta didik akan diarahkan untuk aktif belajar melalui sentuhan (touching), merasakan (feeling) dan melihat (looking) secara langsung serta mengalami sendiri sehingga pembelajaran akan lebih bermakna dan cepat dimengerti oleh peserta didik (Effendi, 2013). Pendidik (guru) akan selalu dituntut untuk memberikan motivasi setiap peserta didik dan memberikan arahan serta menyediakan sarana dan prasarana yang lengkap.

Khotimah dkk (2018) mendefinisikan pembelajaran aktif sebagai pendekatan mengajar (approach to teaching) yang dipakai bersama metode tertentu disertai penataan lingkungan sedemikian rupa agar proses pembelajaran menjadi aktif sehingga peserta didik merasa mudah menyerap pengetahuan dan keterampilan yang diajarkan dan merasa lebih tertarik untuk belajar (Khotimah, 2018). Definisi lainnya adalah pembelajaran yang menuntut peran serta siswa secara aktif dalam mengikuti setiap tahapan proses pembelajaran untuk mencapai hasil yang optimal (Kurniawan, 2020), bertujuan untuk memperkuat dan memperlancar stimulus serta respon peserta didik dalam proses kegiatan pembelajaran, sehingga pembelajaran menjadi hal yang menyenangkan (Rosida, 2011), menggambarkan salah satu pendekatan pembelajaran yang dapat diterima secara luas di seluruh dunia sebagai praktik terbaik (best practice) (Elfrianto, 2020) merupakan suatu cara dalam menyampaikan materi pembelajaran dari seorang guru dengan menggunakan salah satu metode pembelajaran sesuai materi pada topik tertentu yang melibatkan seluruh peserta didik secara aktif dan kreatif (Hidayat, 2020).

Sesuai tuntutan kurikulum, pembelajaran aktif menjadi penting untuk diimplementasikan oleh para pengajar disebabkan beberapa hal: a) paradigma pembelajaran bukan lagi berpusat pada guru (teacher oriented), tetapi harus berpusat pada peserta didik (student oriented) (Yakob, M., dan Sari, 2019), b) implementasi pembelajaran aktif di beberapa sekolah masih kurang maksimal (Elfrianto, 2020), c) beberapa guru di madrasah kurang mempunyai strategi mengajar, kebanyakan masih menggunakan pembelajaran tradisional (Yuanita, 2020), dan d) dominasi guru atas peserta didikmasih kuat, sehingga kurang memberikan peluang pada peserta didik untuk menyelesaikan persoalan yang dihadapi (Suprapto, 2018). 
Salah satu strategi pembelajaran yang dianggap mampu mengaktifkan peserta didik dalam kegiatan pembelajaran adalah pembelajaran aktif MIKiR, yang merupakan singkatan dari mengalami, interaksi, komunikasi dan refleksi. Beberapa peneliti telah melakukan penelitian pada penggunaan strategi pembelajaran ini, diantaranya adalah Elfirianto dkk (2020) yang menunjukkan bahwa; a) kegiatan pendampingan dikatakan berhasil dengan keterlibatan peserta yang antusias dan sangat aktif, b) layanan konsultasi dapat dimanfaatkan secara maksimal oleh peserta, c) pelaksanaan ujian online dapat terlaksana dengan baik meskipun terbatas.

Balai Diklat Keagamaan Bandung, sebagai salah satu lembaga pelatihan pada Kementerian Agama, dengan wilayah kerja seluruh kota dan kabupaten di Jawa Barat, memiliki kewajiban untuk ikut mensosialisasikan dan mengimplentasikan semua hal yang berkaitan dengan strategi pembelajaran aktif kepada seluruh peserta pelatihan.

Salah satu bentuk implementasi yang akan dilakukan pada penelitian ini adalah pendekatan pembelajaran aktif MIKiR ini, dengan rumusan masalah; "Bagaimanakah implementasi pembelajaran aktif MIKiR pada Pelatihan Guru Matematika Madrasah Ibtidaiyah?".

\section{METODE}

Penelitian ini bertujuan untuk mengetahui implementasi pembelajaran aktif MIKiR pada Pelatihan Guru Matematika Madrasah Ibtidaiyah yang dilaksanakan di Balai Diklat Keagamaan Bandung. Subjek penelitian adalah peserta pelatihan yang merupakan utusan dari lima wilayah, yaitu Kota Bandung, Kabupaten Bandung, Kabupaten Bandung Barat, Kota Cimahi dan Kabupaten Sumedang dengan jumlah total sebanyak 30 orang.

Jenis penelitian yang digunakan adalah Pre Experimental Design, dengan menggunakan satu kelas sebagai eksperimen tanpa kelas kontrol. Rancangan penelitiannya digambarkan pada Gambar 1.

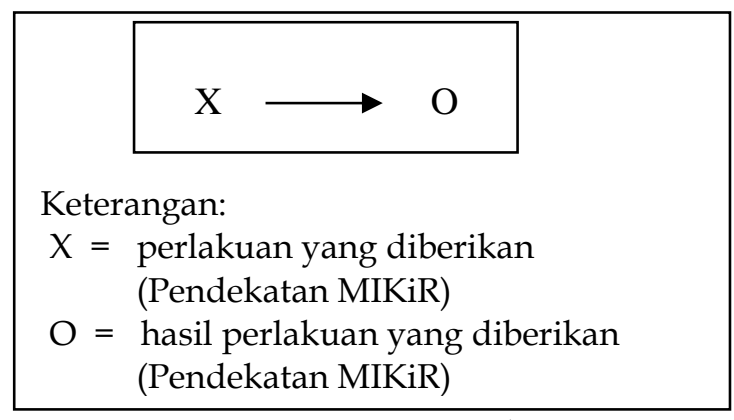

Gambar 1 Desain Penelitian

Metode pengumpulan data yang digunakan adalah metode pengamatan. Teknik analisis data yang digunakan diolah secara deskriptif dengan menggunakan rata-rata dan prosentase, dengan kriteria pada Tabel 1.

Tabel 1 Kriteria Kompetensi

\begin{tabular}{|c|c|}
\hline Kriteria & Rentang Skor \\
\hline Sangat Kompeten & $92,10-100$ \\
\hline Kompeten & $84,10-92,09$ \\
\hline Cukup Kompeten & $76,00-84,09$ \\
\hline Kurang Kompeten & $0-75,99$ \\
\hline
\end{tabular}

Sumber: Pusdiklat, 2017 


\section{HASIL DAN PEMBAHASAN}

Proses pembelajaran pada pelatihan ini berlangsung dari tanggal 4 - 9 Oktober 2021, dengan mata pelatihan yang sudah ditentukan dari Kurikulum dan Silabus yang diterbitkan oleh Pusdiklat, yaitu sebagai berikut: a) Materi Esensial Aspek Bilangan 24 jp, b) Materi Esensial Geometri dan Pengukuran 10 jp, c) Materi Esensial Aspek Statistika dan Peluang, 10 jp. Sehingga jumlah total materi esensial sebanyak $44 \mathrm{jp}$.

Pendekatan pembelajaran dengan menggunakan Strategi MIKiR (Mengalami, Interaksi, Komunikasi dan Refleksi), dengan langkah seperti pada Gambar 2.

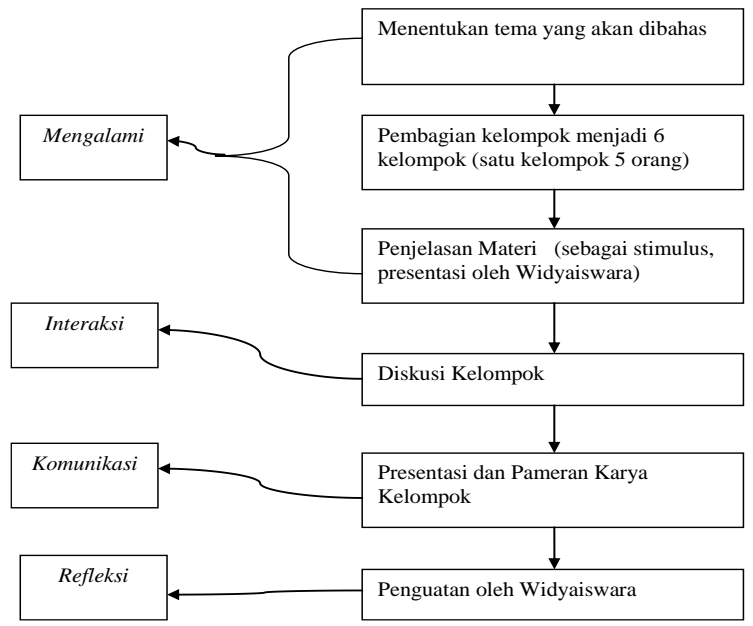

Gambar 2 Alur Pembelajaran

Secara rinci, alur pembelajarannya adalah sebagai berikut;

1. Mengalami

Pada kegiatan ini dijelaskan kepada peserta pelatihan tentang seluruh proses pembelajaran yang akan dilaksanakan pada tiap mata pelatihan. Sedangkan kegiatan yang dilakukan oleh seluruh peserta pelatihan adalah mengamati, melakukan eksperimen, berwawancara dan menyelesaikan proyek. Pada penerapan unsur mengalami ini, dilakukan dengan aktifitas peserta melakukan pengamatan dan percobaan, kegiatan ini bertujuan agar peserta mengalami dan merasakan sendiri secara langsung semua proses pembelajaran. Hampir seluruh indra (melihat, meraba, mencium, mendengar dan merasakan) dilibatkan pada kegiatan ini, sehingga pemahaman konsep akan lebih mengena. Pada kegiatan ini diharapkan pelibatan peserta dapat meningkatkan kreatifitas dan berfikir kritis.

Dari kegiatan mengamati yang dilakukan peserta, widyaiswara memberikan respon dengan: (1) memperhatikan peserta secara individu maupun kelompok selama berlangsung kegiatan dengan memastikan pengamatan dan percobaan yang dilakukan peserta sudah benar dan tepat, mengajukan pertanyaan yang sifatnya terbuka (open ended) sebagai pancingan untuk membangun kemampuan peserta dalam mengembangkan pola berfikirnya, dan (3) memberikan komentar serta penguatan terhadap hasil pengamatan dan percobaan yang telah dilakukan. 
2. Interaksi

Pada proses ini, kegiatan yang dapat dilakukan oleh peserta pelatihan adalah berdiskusi diantara anggota kelompok, bertanya atau mempertanyakan, memberikan komentar dan bekerja dalam kelompok untuk menyelesaikan permasalahan yang sudah diperoleh pada tahap mengamati atau mengalami.

Kegiatan interaksi ini diwujudkan widyaiswara dalam bentuk menginstruksikan peserta untuk berdiskusi dalam kelompok yang sebelumnya sudah dibentuk melalui permainan sekaligus ice breaking, satu kelompok maksimal 5 orang peserta. Pada kegiatan ini diharapkan terbangun interaksi yang positif dan produktif dalam memecahkan dan menemukan hal-hal baru dari kegiatan yang mereka lakukan.

Pengamatan yang dilakukan widyaiswara pada kegiatan interaksi ini adalah: (1) ketika peserta sedang melaksanakan kegiatan diskusi, peserta dipersilahkan untuk saling bertanya, memberikan komentar atau menyanggah, mengemukakan ideide yang relevan, (2) ketika diskusi selesai, salah satu anggota kelompok menjelaskan hasil kerja mereka, dan anggota kelompok yang lainnya memperhatikan, menyimak serta memberikan masukan atau tambahan yang dirasakan masih kurang.
3. Komunikasi

Pada proses ini, kegiatan yang dapat dilakukan oleh peserta pelatihan adalah mendemonstrasikan, menjelaskan, mengemukakan pendapat, atas temuan-temuan yang sudah didiskusikan dengan anggota kelompoknya, yang memungkinkan akan didapatkan hal-hal baru bersadarkan masukan-masukan dari kelompok lainnya, pada tahap ini akan terjadi komunikasi multi arah, yaitu komunikasi antar anggota kelompok.

Pada kegiatan komunikasi ini, pengamatan yang dilakukan widyaiswara adalah; (1) meminta peserta untuk mempresentasikan dan mendemonstrasikan hasil diskusi yang sudah dilakukan di kelompok masing-masing di depan semua peserta dari semua kelompok secara bergiliran, sesuai kesepakatan yang sudah dilakukan, (2) kelompok yang tidak sedang presentasi diharuskan menyimak, menanggapi atau juga bisa menambahkan dari ide-ide lainnya yang mereka temukan.

4. Refleksi

Pada proses ini, kegiatan yang dapat dilakukan oleh peserta pelatihan adalah memikirkan kembali hasil pekerjaannya, baik dalam kelompok maupun di luar kelompoknya. Pada akhir kegiatan refleksi ini, hal yang terpenting adalah penguatan dari pengajar (widyaiswara). Penguatan ini berfungsi untuk meluruskan 
kembali hal-hal yang memungkinkan peserta pelatihan salah memahami konsep.

Hasil akhir yang diharapkan dalam kegiatan pembelajaran, sebagai wujud pemahaman peserta dari implementasi pembelajaran MIKiR yang dilakukan ini adalah dihasilkannya skenario atau desain pembelajaran yang berorientasi MIKiR (mengamati, interaksi, komunikasi dan refleksi), yang akan mereka implementasikan kembali sepulang mereka dari pelatihan ini. Sedangkan proses evaluasi akhir dilakukan dengan memberikan tugas mandiri kepada peserta untuk menyusun skenario/desain pembelajaran. Desain pembelajaran yang dibuat disesuaikan dengan minat masing-masing peserta dari seluruh mata pelatihan yang diberikan. Hasil dari tugas mandiri ini menjadi acuan bahwa peserta pelatihan telah menguasai kompetensi yang diajarkan.

Tabel

2 merupakan skenario/desain pembelajaran yang dikirimkan peserta pelatihan melalui googleform.

Tabel 2 Skenario Pembelajaran

\begin{tabular}{|c|c|c|}
\hline $\begin{array}{c}\text { Materi } \\
\text { Esensial Aspek }\end{array}$ & $\begin{array}{c}\text { Jumlah yang } \\
\text { Dihasilkan }\end{array}$ & Prosentase \\
\hline Bilangan & 18 & 60,00 \\
\hline $\begin{array}{c}\text { Geometri dan } \\
\text { Pengukuran }\end{array}$ & 5 & 16,67 \\
\hline $\begin{array}{c}\text { Statistika dan } \\
\text { Peluang }\end{array}$ & 7 & 23,33 \\
\hline
\end{tabular}

Sumber: Data Diolah
Berdasarkan tugas-tugas yang dikumpulkan oleh peserta pelatihan, diperoleh hasil pada Tabel 3, 4 dan 5.

Tabel 3 Nilai Aspek Sikap

\begin{tabular}{|c|c|c|c|}
\hline Nilai & F & $\%$ & Kualifikasi \\
\hline $92,10-100$ & 3 & 10 & $\begin{array}{c}\text { Sangat } \\
\text { Kompeten }\end{array}$ \\
\hline $84,10-92,09$ & 27 & 90 & Kompeten \\
\hline
\end{tabular}

Sumber: Data Diolah

Aspek sikap diambil dari respon peserta pelatihan dalam mengikuti proses pembelajaran, kedisiplinan dalam kehadiran dan berpakaian. Aspek sikap ini diambil sebanyak 20\% untuk digabungkan dengan kompetensi pengetahuan dan aspek keterampilan. Berdasarkan pengolahan data, diperoleh rata-rata keseluruhan untuk aspek sikap ini adalah 89,60 (delapan Sembilan koma enam puluh).

Tabel 4 Nilai Aspek Pengetahuan

\begin{tabular}{|c|c|c|c|}
\hline Nilai & F & $\%$ & Kualifikasi \\
\hline $92,10-100$ & 9 & 30 & $\begin{array}{c}\text { Sangat } \\
\text { Kompeten }\end{array}$ \\
\hline $84,10-92,09$ & 21 & 70 & Kompeten \\
\hline
\end{tabular}

Sumber: Data Diolah

Aspek pengetahuan diperoleh dari nilai pretest dan posttest, tes lisan yang diikuti selama proses pembelajaran, serta tugas akhir berupa skenario/desain pembelajaran dengan pendekatan MIKiR yang mereka kerjakan dan dikirimkan melalui googleform. Nilai pengetahuan ini diambil sebanyak $40 \%$ untuk digabungkan dengan kompetensi sikap dan kompetensi keterampilan. Nilai rata-rata keseluruhan untuk 
kompetensi pengetahuan ini adalah 90,17 (Sembilan puluh koma tujuh belas).

Tabel 5 Nilai Aspek Keterampilan

\begin{tabular}{|c|c|c|c|}
\hline Nilai & F & $\%$ & Kualifikasi \\
\hline $92,10-100$ & 6 & 20 & $\begin{array}{c}\text { Sangat } \\
\text { Kompeten }\end{array}$ \\
\hline $84,10-92,09$ & 24 & 80 & Kompeten \\
\hline
\end{tabular}

Sumber: Data Diolah

Aspek keterampilan diperoleh dari aktifitas peserta pelatihan dalam mengerjakan tugas-tugas, baik secara individu maupun kelompok, presentasi dalam kelas, keaktifan dalam mengajukan pertanyaan atau menjawab pertanyaan ketika kelompok yang lain presentasi. Nilai keterampilan diambil sebanyak $40 \%$ untuk digabungkan dengan kompetensi sikap dan kompetensi pengetahuan. Nilai ratarata keseluruhan 89,88 (delapan sembilan koma delapan delapan).

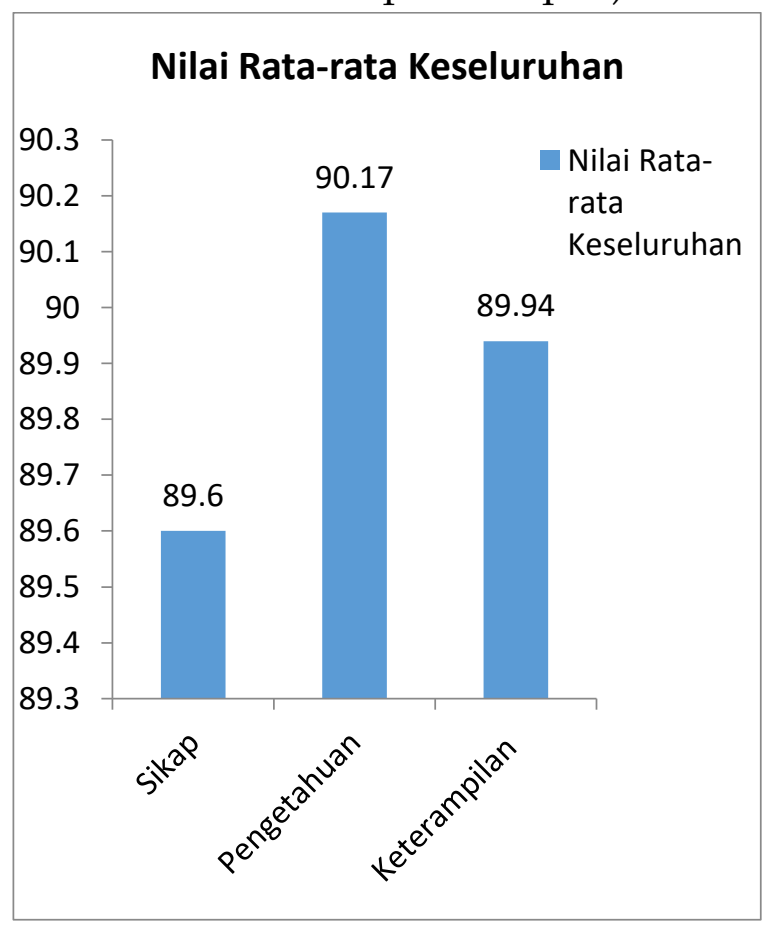

Gambar 2 Grafik Nilai Rata-rata Tiap Aspek
Berdasarkan Grafik 1 di atas, terlihat bahwa nilai rata-rata peserta pelatihan, tertinggi pada aspek pengetahuan, yaitu sebanyak 90,17. Hal ini diperoleh berdasarkan tugas akhir yang dikumpulkan peserta pelatihan, yaitu menyusun skenario/desain pembelajaran, dengan menggunakan pendekatan MIKiR (mengamati, interaksi, komunikasi dan refleksi).

Tabel 6 Nilai Keseluruhan

\begin{tabular}{|c|c|c|c|}
\hline Nilai & F & $\%$ & Kualifikasi \\
\hline $92,10-100$ & 6 & 20 & $\begin{array}{c}\text { Sangat } \\
\text { Kompeten }\end{array}$ \\
\hline $84,10-92,09$ & 24 & 80 & Kompeten \\
\hline
\end{tabular}

Sumber: Data Diolah

Nilai keseluruhan adalah gabungan dari kompetensi sikap sebanyak 20\%, kompetensi pengetahuan sebanyak $40 \%$ dan kompetensi keterampilan sebanyak $40 \%$, sehingga total keseluruhan $100 \%$. Berdasarkan table di atas, dari 30 peserta pelatihan, 6 orang berpredikat sangat kompeten, dan sisanya 24 orang berpredikat kompeten. Rata-rata nilai keseluruhan ini adalah 89,94 (delapan sembilan koma sembilan empat).

\section{KESIMPULAN}

Berdasarkan

hasil dan pembahasan yang telah diuraikan di atas, diperoleh kesimpulan bahwa implementasi pembelajaran aktif MIKiR berhasil meningkatkan kompetensi peserta pelatihan aspek sikap dengan rata-rata 89,60 , pengetahuan dengan rata-rata 90,17 maupun keterampilan 
dengan rata-rata 89,88. Secara keseluruhan diperoleh rata-rata 89,94.

Berdasarkan simpulan di atas, maka direkomendasikan kepada:

1. Widyaiswara, untuk mensosialisasikan dan mengimplementasikan pembelajaran aktif MIKiR ini pada tiap jenis pelatihan pendidikan.

2. Berdasarkan pengalaman peserta dalam mengimplementasikan pembelajaran aktif MIKiR selama pelatihan dan scenario pembelajaran yang dihasilkan, maka peserta (guru) diharapkan dapat mengimplementasikan kembali pembelajaran aktif MIKiR ini di satuan pendidikannya masingmasing disesuaikan dengan kebutuhan dan karakteristik mata pelajaran yang diampunya.

3. Peneliti, untuk melakukan penelitian experimental atau penelitian lainnya yang lebih mendalam tentang implementasi pembelajaran aktif MIKiR ini.

\section{DAFTAR PUSTAKA}

Abdullah. (2017). Pendekatan dan Model Pembelajaran yang Mengatifkan Siswa. Dureligia, 1(1).

Effendi, M. (2013). Integrasi Pembelajaran Active Learning dan Internet-Based Learning dalam Meningkatkan Keaktifan dan Kreatifitas Belajar. Nadwa, Jurnal Pendidikan Islam, 7(2).

Elfrianto, D. (2020). Implementasi Pembelajaran Aktif Berorientasi Mikir (Mengamati, Interaksi, Komunikasi dan Refleksi) di SD Muhammadiyah 12 Medan. Pelita Masyarakat, 2(1).

Gani, Abd., dan M. (2021). Peningkatan Kompetensi Pembelajaran Berbasis Saintifik melalui Rektifikasi Hasil Supervisi Pembelajaran di SMA Negeri 3 Barru Provinsi Sulawesi Selatan. Jurnal Kewidyaiswaraan, 6(1).

Hidayat, D. (2020). Metode Pembelajaran Aktif dan Kreatif pada Madrasah Diniyah Takmiliyah di Kota Bogor. Edukasi Islami: Jurnal Pendidikan Islam, 9(1). https://doi.org/10.30868/ei.v9i01.639

Kadariah. (2018). Penerapan Strategi Pembelajaran Aktif Tipe Everyone is A Teacher Here (ETH) untuk Meningkatkan Hasil Belajar Siswa Kelas V SD Inpres BTN Pemda Kota Makasar. JEKPEND Jurnal Ekonomi Dan Pendidikan, 1(2), 15-22.

Khotimah, D. (2018). Peningkatan Hasil Belajar Matematika Siswa Sekolah Dasar Melalui Penerapan Pembelajaran Aktif Metode Card Short. JPD: Jurnal Pendidikan Dasar, 9(2). https://doi.org/doi.org/10.21009/JPD.091.03

Kurniawan, Y. dan. (2020). Implementasi Pak Buya (Pembelajaran Aktif dan Budaya Baca) Mewujudkan Excelence School di Sekolah Dasar. ELSE (Elementary School Education Journal), 4(2).

Novianingsih, H. (2016). Pendekatan Pembelajaran Aktif, Kreatif, Efektif dan Menyenangkan dalam Pembelajaran Matematika Sekolah Dasar. Jurnal Pendidikan Guru Sekolah Dasar, 1(1), 1-11. 


\section{Wawasan:}

Jurnal Kediklatan Balai Diklat Keagamaan Jakarta PISSN: 2548-9232; EISSN: 2775-3573

Volume 2 Nomor 2 Tahun 2021: 134-143

Rosida, S. (2011). Pengaruh Pembelajaran Aktif dalam Meningkatkan Prestasi Belajar Fisika pada Siswa Kelas 2 SMU. Proyeksi, 6(2), 89-102.

Saefuddin, A. \& I. B. (2014). Pembelajaran Efektif. PT. Remaja Rosdakarya Offset.

Suprapto, K. dan. (2018). Model Pembelajaran Active Learning dengan Strategi Pengajuan Pertanyaan untuk Meningkatkan Kualitas Proses pemnbelajaran PKn. EducatiO, 2(1).

Yakob, M., dan Sari, M. (2019). Peningkatan Kemampuan Siswa SMP Membaca Puisi dengan Metode Pembelajaran Aktif Kreatif dan Menyenangkan. Journal of Education, Humanimora and Social Science (JEHSS), 2(1), 93-103.

Yuanita, D. I. (2020). Penerapan Strategi Pembelajaran Aktif dalam Meningkatkan Motivasi Belajar Aswaja Siswa di Madrasah. Bidayatuna, 3(1). 